\title{
Sustainable Development: The Role of Scientific Literature in Dutch Municipal Spatial Planning
}

\author{
Lucas Vroom $^{1} \&$ Fennie M. van Straalen ${ }^{1}$ \\ ${ }^{1}$ Department of Human Geography and Spatial Planning, Utrecht University, The Netherlands \\ Correspondence: Fennie M. van Straalen, Department of Human Geography and Spatial Planning, Utrecht \\ University, P.O. Box 80.115, 3508 TC Utrecht, The Netherlands. Tel: 31-30-253-7336. E-mail: \\ f.m.straalen@uu.nl
}

Received: January 11, 2016 Accepted: February 15, 2016 Online Published: March 30, 2016

doi:10.5539/jsd.v9n2p193

URL: http://dx.doi.org/10.5539/jsd.v9n2p193

\begin{abstract}
The objective of this article is to show how Dutch municipalities use scientific literature about sustainable development in their spatial planning policies and processes. The approach to this research is twofold. First, we conducted a literature review that summarized the most important discourses in the international and Dutch literature. Secondly, we interviewed Dutch municipalities and asked them how they interpret and define sustainable (spatial) development, how they keep up with the quick developments surrounding sustainability and how they approach sustainable development in their own planning practices. Results show that many municipalities claimed to interpret sustainable development in a broad manner and claim to use a sufficient amount of scientific literature, but their planning practices suggest otherwise. We conclude that the trichotomy 'international scientific literature - national professional literature - planning practice' is not self-evident within Dutch sustainable (spatial) development.
\end{abstract}

Keywords: sustainability, sustainable development, spatial planning, The Netherlands, municipalities

\section{Introduction}

After nearly thirty years, it has become clear that the concept of sustainability is not as straightforward to work with as was expected in 1987 with the publication of 'Our Common Future' by the Brundtland Commission. The Brundtland report positioned sustainability and sustainable spatial development in the worldwide centre point of interest (Blewitt, 2008; Imran, Alam \& Beaumont, 2011; Christen \& Schmidt, 2012; Barkemeyer, Holt, Preuss \& Tsang, 2014). And with good reason: sustainable development was, and is, thought to be able to tackle some of the most fundamental challenges mankind is facing (Hopwood, Mellor \& O'Brien, 2005). This impact is the reason that - despite being introduced almost thirty years ago - the subject is still current in today's society, which is clearly shown in the prominent position of sustainability in nowadays planning policies. Yet, not only the possibilities that sustainability offers renders its prominent position after almost thirty years; but also the complexity of the concept. Although the Brundtland report provides a (broad) definition of sustainable development, academics are still debating the definition and content of the concept. The only thing that is rather clear, is that consensus is far from being achieved (Kambites, 2012, De Jong, Joss, Schraven, Zhan \& Weijnen, 2015).

Sustainability and sustainable spatial development are very complex concepts whereupon many different views, interpretations and definitions exist. Moreover, one of the most profound problems is the gap between international theoretical literature (e.g. Campbell, 1996; Luke, 2005, Imran et al., 2011; Kambites, 2012), national professional literature, and the implementation of sustainability via planning practices. Dutch literature for example entails some theoretical notions (e.g. Duijvestein, 2003; Van de Griendt, 2011; Koops, 2012; Felix, 2015), but critical reflection on the (practical) use of sustainability or sustainable development is lacking (Sharachchandra, 1991; Luke, 2005; Gough, Scott \& Stables, 2010). The problem that derives hereof is the struggle of governmental agencies, municipalities in particular, to deal with the complexity of these concepts in practice. In the midst of all these definitions and interpretations the concept of sustainability is at danger of becoming a mere tool that one can use for its own benefit (Kambites, 2012; Hopwood et al., 2005) wherein certain groups only use the concept to brand their ideas, rather than incorporate a holistic pathway for the implementation of sustainability. As such, chances are sustainability will become a meaningless concept and that 
is, given the potential of the concept, something that is best prevented (Hopwood et al., 2005).

Although some studies started to link international literature, national literature, and sustainable practices (Carr \& Krueger, 2011; Raco, 2013) rigorous analysis off the relation between these three components is still scarce within the international academic debate. As such, the extent of the mentioned gap between international literature, national literature and planning practices is still unknown and, more importantly, there is no insight in the link between scientific and practical application of the sustainability concepts. This research wishes to better understand the use of scientific literature in policies and in project-based application of sustainability in spatial development. Therefore the objective of this research is twofold. First, we opt to understand how national professional literature has elaborated from international literature and how both scientific and professional literature affects the implementation of sustainable development in municipal planning practices. This will provide insight in the gaps that exist within the trichotomy 'international scientific literature - national professional literature - planning practice'. Second, we opt to begin narrowing the gap between science and society by offering more insight to municipalities into the scientific debate about sustainable spatial development (during the study). We hope that the interviewed municipalities, and other municipalities who come across this research, will henceforth be more percipient about the choices they make concerning sustainable spatial development and the way sustainable policies are shaped. The objective is translated in the following research question: "Which literature do municipalities use to interpret and define sustainability and sustainable spatial development, how do they cope with the fast development of these concepts and how are choices made in regard to these concepts?".

The research focusses on spatial planning as mechanism for the implementation of sustainable development. Municipalities were chosen as research objects because they are one of the lowest forms of government and directly responsible for the implementation of sustainable objectives in planning processes. Furthermore, as there are multiple municipalities we assume there are very diverse ways for dealing with sustainable development. Finally we focussed on the Netherlands for two reasons. First, the Netherlands have a longstanding planning system with a strong municipal level, responsible for the implementation of spatial objectives such as sustainable development. Second, the urgency for Dutch municipalities to become more sustainable is becoming more severe by the day. A prime example of that mounting pressure on authorities is a lawsuit filed, and won, by the non-profit organization Urgenda against the Dutch government forcing them to be more active in getting sustainable.

In the following section of this article the research approach is explained. Herein the choices concerning the research will be explained as well as the implications those choices had for the results. Afterwards, the findings of the research are presented and discussed. This section is divided into three parts; the first result section deals with the literature review and discourses in international literature. The second result section examines discourses in Dutch literature. The third section discusses the practical application of sustainable development in the Netherlands. Finally, in the discussion and conclusion section, the main research question is answered, the results of this study are discussed and propositions are made for a possible follow up study.

\section{Research Approach}

To conduct this research two types of data collection were used: literature review to analyse the international and national (Dutch) literature and semi-structured interviews to collect empirical data of sustainable development at the municipal level.

We choose qualitative sampling to collect municipal data to be able to collect underlying ideas and interpretations that drive municipalities in their (sustainable) planning practices. It is easy for municipalities to publish policy papers and refer to these in, for example, questionnaires. During interviews, carefully formulated questions can pierce trough the policy facade and gain access to the reality of the implementation of sustainable objectives within municipalities. As such, the goal of these interviews is to get a clear image for each municipality in how they interpret and define sustainability and sustainable spatial development and how they implement current sustainable developments.

The literature review focussed on the concepts of sustainability, sustainable development, spatial development and sustainable spatial development. The search was conducted by using several search engines, namely: Google Scholar, Scopus and Picarta. In table 1 the used search terms and the amount of hits in Scopus is mentioned to provide insight in the number of hits per search term. The analysis of the literature was conducted as a (simplified) discourse analysis. The goal hereof was identification of the different discourses surrounding the concepts of sustainable spatial development. Afterwards the way the different discourses arose and evolved was analyzed. First international literature was analyzed and afterwards Dutch literature, including the manner in 
which international discourses reflect in Dutch literature

Table 1. Overview of the used search terms and the accompanying amount of hits via Scopus

\begin{tabular}{lll}
\hline Search term & Translation (if applicable) & Hits \\
\hline Sustainability & & 81.492 \\
Sustainable development & & 136.013 \\
Sustainable area development & & 109 \\
Sustainable spatial development & & 5.806 \\
Duurzaamheid & (sustainability) & 19 \\
Duurzame gebiedsontwikkeling & (sustainable area development) & 1 \\
Duurzame ontwikkeling & (sustainable development) & 3 \\
Gebiedsontwikkeling & (area development) & 4 \\
\hline
\end{tabular}

When discussing discourse, the first thing to acknowledge is that there is no single definition of discourse. Schmidt (2008) sees discourse as 'the interactive process of conveying ideas' (p. 303) whereas Lister et al. (2003) define discourse as 'the communication of a certain group at a certain level in which that group structures reality and implicitly captures what they hold as morality and truth' (Lister, Dovey, Giddings, Grant \& Kelly, 2003). Scientists who are dealing with discourse do not regard humans as homo economicus or homo sociologicus but rather as homo interpreter. By this, they mean that people do not act out of ratio or social norms and values but rather out of (collective) ideas and interpretations of the world (Arts \& Buizer, 2009). Discourse is therefore, seen as the outcome of human (inter)action. And this 'action' includes what someone said, how someone said it, why someone said it and in which context someone said it. This context includes the background of every single person, as that determines how a person perceives reality. Moreover, discourse is not only used to describe a certain reality, but reality can only been perceived through discourse. Another interesting view on discourse is the divide between 'thick' and 'thin' constructivists. Thin constructivists argue that discourse can be changed through discussion whereas thick constructivists believe the impact of humans on discourse is minimal and that discourse only slowly changes with time (Hajer, 1995; Van den Brink \& Metze, 2006; Holzscheiter, 2014).

Additionally, a number of views can be distinguished within discourse analysis. Some examples are discourse as text, discourse as communication, discourse as frame, and discourse as social practice (Arts \& Buizer, 2009). In daily life discourse is often associated with discussion. This view can also be applied to discourse at a more scientific level. Habermas (1996) understands de involvement of society in deliberations as ideal when the balance of power is totally equal and the best argument wins the discussion. What is seen is that the concept of sustainability has changed over time and that change was mostly propelled by (scientific) discussion. So this article has been written from a thin constructivist point of view whereby discourse is viewed as communication and discussions are used to elaborate and evolve sustainability and sustainable development.

After the literature review was conducted we interviewed civil servants to gain insights in the discussions about sustainable development and practice and to test the extent of the gap between literature and practice. We conducted 10 interviews with Dutch (municipal) civil servants of 10 different municipalities in the Netherlands who are involved in spatial planning and sustainable development. The positions of the civil servants included project manager, policymakers, policy-advisors, alderman, and one urban planner. The municipalities were chosen based on their size (number of inhabitants) and location (centre, semi-periphery and periphery). We opted for disparity in size and location to ensure a broad and varied picture of how municipalities cope with the concept of sustainable spatial development, see figure 1and table 2. Additionally, in figure 1 a map of the Netherlands is shown with the municipalities that were approached but weren't interviewed in red and the interviewed municipalities in blue to show the disparity in location. The numbers depicted in the map correspond with the names of the municipalities in the legend.

The empirical data gained during interviews has been analysed by encoding the transcripts of the interviews. Based on the research objective several themes have been formulated, namely: 1) description and interpretation, 2) definition, 3) choice foundation, 4) use of scientific sources, 5) keeping up with developments, 6) policy actualization, 7) ambitions, and 8) willingness to invest, see table 3. 


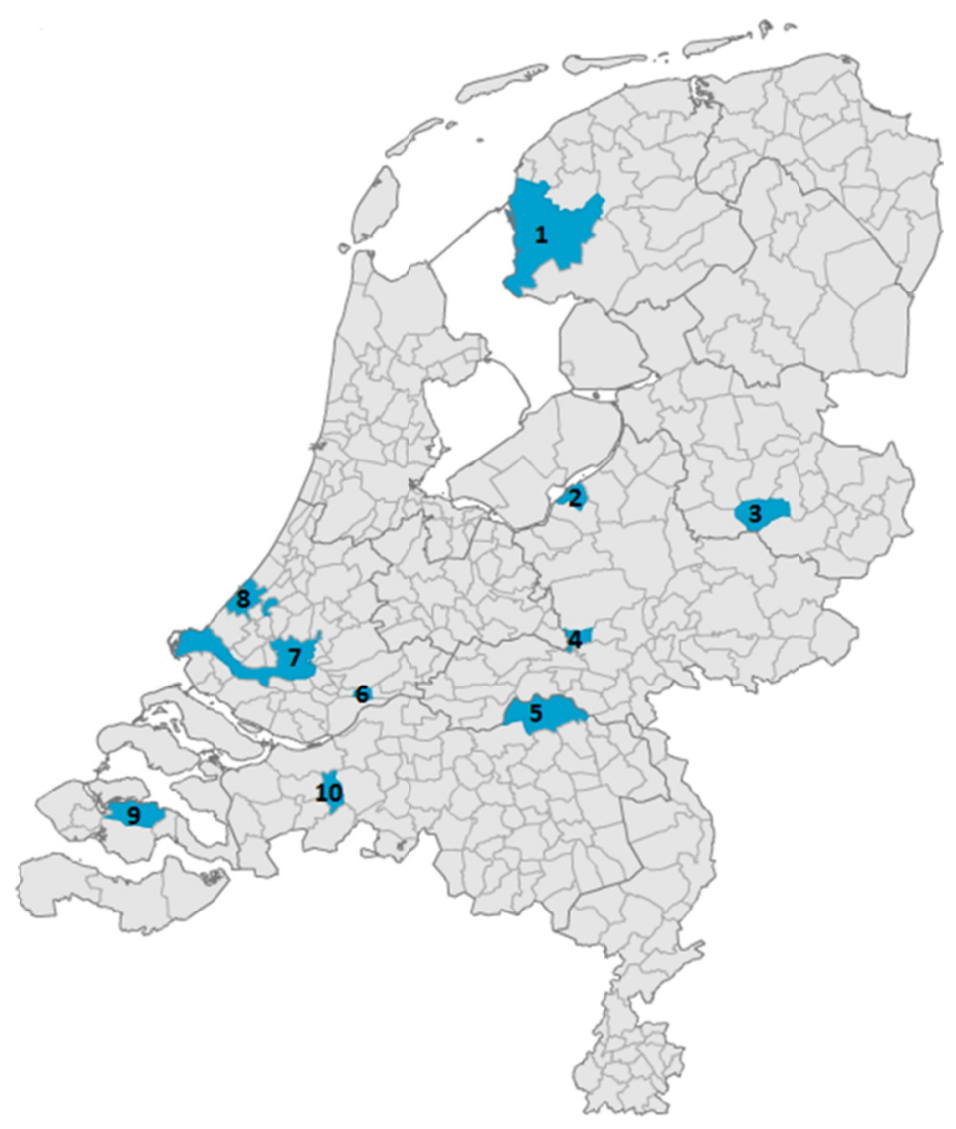

Figure 1. Overview of the interviewed municipalities

Legend: 1 Súdwest-Fryslân; 2 Harderwijk; 3 Rijssen-Holten; 4 Wageningen; 5 Oss; 6 Sliedrecht; 7 Rotterdam; 8 Den Haag; 9 Goes; 10 Etten-Leur.

Table 2. Overview of the approached and interviewed municipalities and their size

\begin{tabular}{lll}
\hline Municipality & Number of inhabitants (Source CBS, 2015) \\
\hline 1 & Súdwest-Fryslân & 84.164 \\
2 & Harderwijk & 45.776 \\
3 & Rijssen-Holten & 37.830 \\
4 & Wageningen & 37.786 \\
5 & Oss & 89.799 \\
6 & Sliedrecht & 24.758 \\
7 & Rotterdam & 623.652 \\
8 & Den Haag & 514.861 \\
9 & Goes & 37.153 \\
10 & Etten-Leur & 42.503 \\
\hline
\end{tabular}


Table 3. Overview of the used themes during analysis of the interviews

\begin{tabular}{|c|c|}
\hline Theme & Content \\
\hline Description and interpretation & $\begin{array}{l}\text { The manner in which municipalities interpret sustainability and sustainable } \\
\text { spatial development. For example, do the municipalities interpret } \\
\text { sustainability in a very broad manner, or are they only focussing on certain } \\
\text { aspects such as co2 reduction. }\end{array}$ \\
\hline Definition & $\begin{array}{l}\text { Whether municipalities have formulated or chosen a clear definition of } \\
\text { sustainability and/or sustainable spatial development and the underlying } \\
\text { thoughts regarding the choices that have been made are clear. }\end{array}$ \\
\hline Choice foundation & $\begin{array}{l}\text { The way municipalities make their choices regarding sustainability and } \\
\text { sustainable spatial development. Do they simply follow standards that are } \\
\text { imposed by the government which implies a low level of involvement to } \\
\text { sustainability or are they actively involved in making policy that goes beyond } \\
\text { federal standards which indicates a higher level of involvement regarding } \\
\text { sustainability? }\end{array}$ \\
\hline Use of scientific sources & $\begin{array}{l}\text { A pragmatic approach does not necessarily have to be a bad approach. It too } \\
\text { can be well substantiated. Nevertheless a sound scientific foundation of } \\
\text { municipal policy can be seen as an indicator of how intensive a municipality } \\
\text { is dealing with sustainability and sustainable spatial development. }\end{array}$ \\
\hline Tracking developments & $\begin{array}{l}\text { The manner in which municipalities remain up to date in regard to } \\
\text { developments that take place within the scientific debate as well as more } \\
\text { practical, technological developments. Two ways that are used can be } \\
\text { distinguished: a passive and active manner. Using the passive way } \\
\text { municipalities create a framework in which other actors can create their plans } \\
\text { and thus are responsible for keeping up to date with new developments. } \\
\text { When the active way is used it are the municipalities itself that make sure } \\
\text { new developments are found and used and thus requires more effort. }\end{array}$ \\
\hline Policy actualization & $\begin{array}{l}\text { The manner in which new developments in science not only taken up in } \\
\text { policies, but are being used and integrated in new plans. }\end{array}$ \\
\hline Ambitions & $\begin{array}{l}\text { The degree to which municipalities are prepared to go the extra mile is the } \\
\text { subject of this theme. How great are their ambitions? Which municipalities } \\
\text { think it is enough to simply comply to federal standards and which are } \\
\text { determined to do something extra? The reasons behind these differences in } \\
\text { ambitions are also clarified here. }\end{array}$ \\
\hline Willingness to invest & $\begin{array}{l}\text { The willingness to invest in sustainable spatial development gives a good } \\
\text { insight, especially in these times of economic scarcity, of the measure to } \\
\text { which an municipality is concerned with sustainability. }\end{array}$ \\
\hline
\end{tabular}

\section{Results Part 1: Discourses in International Literature}

In our elaboration on the most important concepts surrounding sustainable spatial development in international literature, the evolution of the sustainability discussion will serve as a guideline. This means that we will start in 1980 when the term sustainable development was first used by the 'World Conservation Strategy' (Hopwood et al., 2005). Seven years later the Brundtland commission published its report 'Our Common Future' (World Commission on Environment and Development [WCED], 1987), which accelerated the discussion surrounding sustainability (Kambites, 2012; Hopwood et al., 2005; Imran et al, 2011). The Brundtland report also introduced one of the most widely used definitions for sustainable development, namely: 'Sustainable development is development that meets the needs of the present without compromising the ability of future generations to meet their own needs.' (WCED, 1987). Ever since the Brundtland report positioned sustainability and sustainable development in the center of international interest and propelled the discussion surrounding concept, there has been an ongoing discussion about the definition and content of sustainability and sustainable development. The origins of this discussion are founded in the Brundtland report itself. Although widely spread, the definition of 
sustainability in the Brundlandt report remains quite vague. Imran et al. (2011) argues this has been done with purpose to gain political support, as anyone can interpret it the way he or she prefers and thus making it difficult to reject this definition. Aside from the reasoning behind the definition, its vague character has led to a great number of views, interpretations and definitions of sustainable development of which the most important ones will be shortly discussed hereafter.

One of the most fundamental discussions surrounding the debate about sustainability is the anthropocentric versus the ecocentric view. The anthropocentric view puts humans at the center of sustainability, whereby sustainability focuses on meeting the needs of humans as efficient as possible. Still, this does not necessarily mean that anthropocentrists do not care about the environment. The ecocentric view on sustainability is exactly the opposite. Ecocentrists focus on protecting the environment first, whereas human needs come second (Imran et al., 2011). When taking a look at the definition of sustainability in the Brundtland report it is clear that it has an anthropocentric orientation; it focusses on the needs of humans first (Barkemeyer et al., 2014). The anthropocentric nature of the Brundtland report is reinforced by the following statement that can be found in the report: : 'Species and ecosystems must be preserved because they have an economic value that is deemed crucial for development and important to human welfare' (WCED, 1987, p. 147). Bond and Saunders (2009) argue that the essence of the concept of sustainability, namely protecting and preserving the environment, has been lost as a result of nowadays focus on economic value. This ensures that the broader - ecocentric - sustainable perspective has been lost in favor of economic perspectives.

A different discussion that follows along the path of the debate surrounding anthropocentrism and ecocentrism is the debate surrounding strong and weak sustainability (Haughton \& Hunter, 1994). Weak sustainability views natural and fabricated capital as exchangeable with the help of technology. As such technology is capable of filling holes in nature that were created by humans. An extreme view within this debate was given by Solow (1974) who stated that by replacing natural resources by other aspects the world can do without natural resources, which means that the exhaustion of the earth is a mere event instead of a disaster. Weak sustainability can therefore be seen as a form of a anthropocentric view on sustainability which places humankind at the center point (Haughton \& Hunter, 1994; Daly \& Cobb, 1989). Logically, strong sustainability is on the other side of the spectrum, stating that humankind does not possess the required capacities to support nature and fill the holes created by mankind. Supporters of strong sustainability point out that humans are not capable of recreating natural processes such as photosynthesis (Rees \& Roseland, 1988).

Campbell (1996) brings a view on sustainable development to the table that offers some nuance to the debate between anthropocentrism and ecocentrism. He states that there are three pillars on which sustainability, or sustainable development, rests: a social, an economical, and an environmental pillar. Between the three pillars a number of conflicts exist (see figure 1). Campbell states that in the years to come planners will face those conflicts in order to achieve sustainable development. However, these conflicts are not just superficial problems. On the contrary, they go back to the core of the sustainability quest (Campbell, 1996). To understand the different interests and the conflicts, Campbell developed a triangular model which he named 'the planners triangle'. The crux of his plea is that to achieve truly sustainable development, all three pillars have to be integrated in a plan and thus have to tackle all three conflicts simultaneously: the property conflict, the development conflict and the resource conflict (Campbell, 1996; Elkington, 1997). In the same years that Campbell introduced his model, Elkington (1997) developed his Triple P model. The base of the Triple P approach is largely similar to Campbells model and is also based on three pillars, an economical, a social, and an environmental pillar. The difference between both models can be found in the terminology used. Elkington has a more populist approach, acuminated to corporate life. For example, he calls the different pillars; people, planet and profit. Nevertheless, this approach is also used in planning practice (Elkington, 1997; Graafland, 2002; Kleindorfer, Singhal \& Wassenhove, 2005; Tanguay, Rajaonson, Lefebvre \& Lanoie, 2010). 


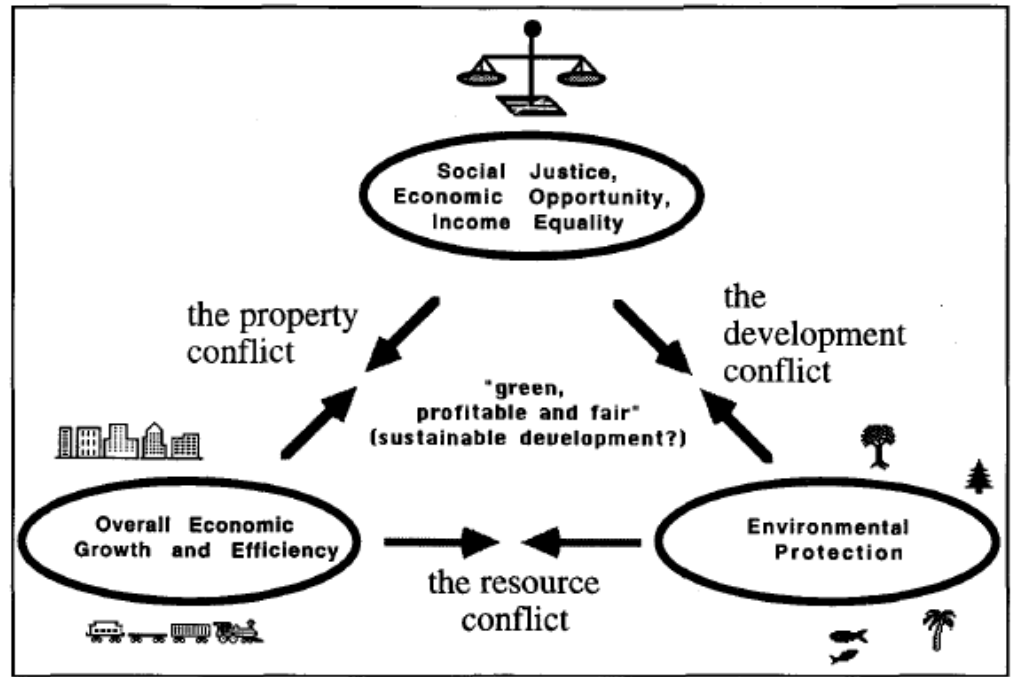

Figure 2. Campbells Triangular Model (Campbell, 1996)

Besides the different views on sustainable development there are also differences in the willingness to change and be more sustainable. Hopwood et al. (2005) distinguishes three groups, namely: status quo, reform and transformation. Supporters of the status quo group believe that change is important, but they do not think that the environment or society as a whole is facing insuperable challenges. Problems can be addressed without fundamental changes in the balance of power or society itself. Supporters of the reform group acknowledge that there are mounting problems and are predominantly critical towards current trends in society and corporate policies. They look for the cause of the mounting problems within a lack of knowledge. However, they do not believe in a total collapse of ecological or social systems. (Pearce, Markandy \& Barbier, 1989; Hawken, Lovins \& Lovins, 1999; Hopwood et al., 2005). Supporters of the transformationist group are most extreme in their views. They see constantly mounting problems in both environment and society. According to them these problems are rooted in the fundaments of our society. Radical changes or a revolution are, according to transformationists necessary to avoid a crisis or even a total collapse of society. The big difference with the other two groups is that this group puts nature first and thereby adopts a ecocentric view on sustainability.

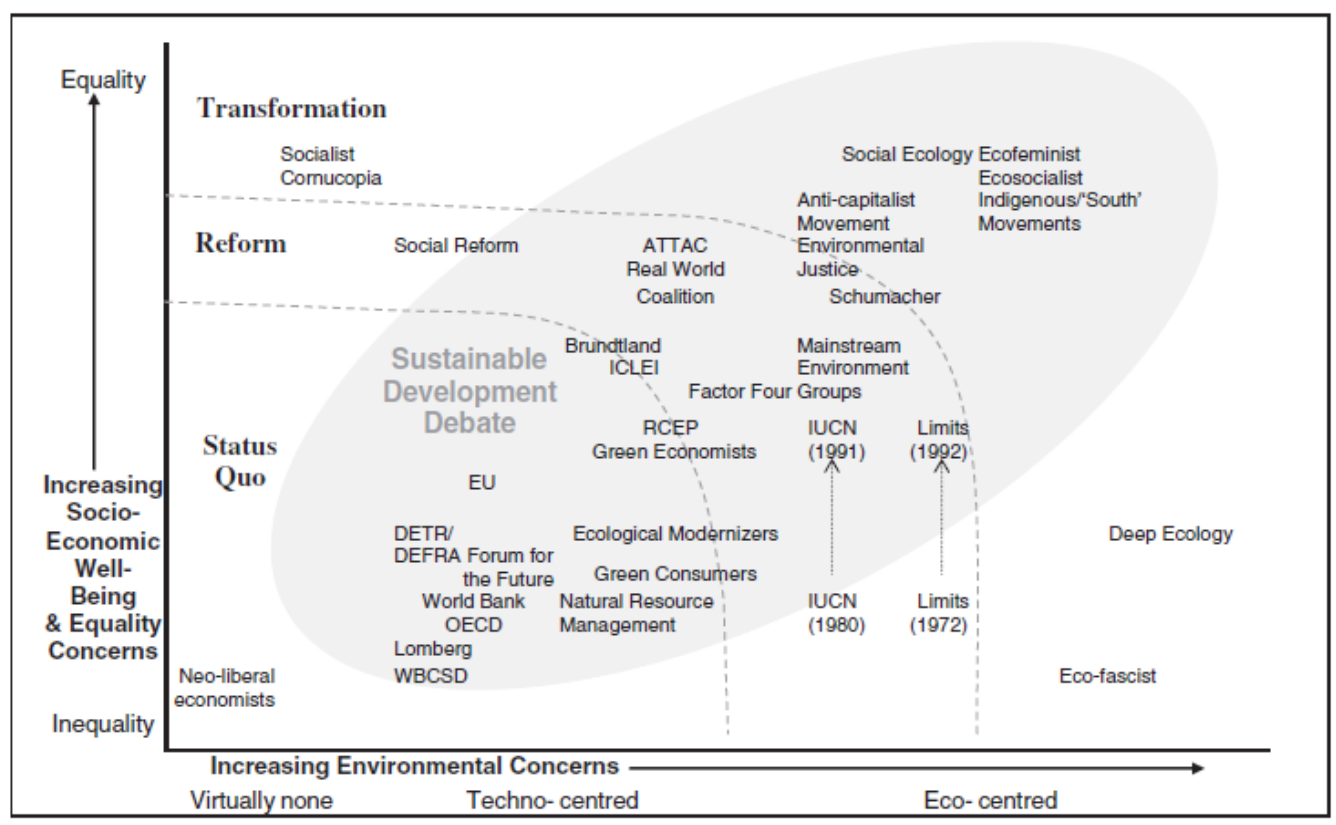

Figure 3. division of different concepts of sustainability (Hopwood et al., 2005) 


\section{Results Part 2: Discourses in Dutch Literature}

The two most asked questions in Dutch literature are 'what exactly is sustainable development?' and 'How can you achieve that?'. Although these questions are answered in a practical manner, there are virtually no theoretical 'schools' to distinguish. There are, for example, no texts about fundamental scientific discussions, such as the anthropocentric versus ecocentric debate. The more practical solutions offered include green-blue networks in sustainable spatial development (Opdam, 2009), inspiring sustainable projects (Feberwee, Mohammadi, Husslage \& Van Timmeren, 2010), how to achieve sustainable development in ten steps (De Zeeuw, 2011), and how to protect the environment and achieve sustainability during spatial development (Van de Griendt, 2011). So the Dutch literary tradition of sustainability concerns the implementation of sustainability via planning projects, rather than debating theories behind its implementation.

Still, Dutch literature is based on several approaches found in international literature. The Brundtland report, Campbells model (1996) and the Triple P Approach (Elkington, 1997), form the theoretical foundation of Dutch literature. For example, the definition of sustainable development offered by Brundtland is found multiple times in Dutch literature (e.g. Feberwee et al., 2010; Van de Griendt, 2011; De Zeeuw, 2011). The Brundtland definition of sustainability is present even when not directly quoted, furthermore the message of the Brundtland report is just as prominent now as it was several years ago in Dutch literature (Duivensteijn, 2003; Opdam, 2009; De Zeeuw, 2009; Kistenkas, 2014).

When the implementation of sustainability is concerned, Dutch literature often mentions or relates to Campbells model and the Triple P approach (Campbell, 1996; Elkington, 1997). In particular Elkingtons Triple P approach is mentioned often as it has a more practical approach and easier accessible language. Nevertheless, both Elkington and Campbell can be found regularly in Dutch literature (Opdam, 2009; Feberwee et al., 2010; Van de Griendt, 2011; De Zeeuw, 2011). In some cases it is tried to offer a theoretical extension of existing literature. An example is Duijvesteijn (2003) who introduced the 'sustainable building tetraëder'. This approach adds one more pillar known as 'space / project' to represent the relationship with the environment, visual quality, spatial composition and structure whereby the added pillar is meant to act like a guide in how to deal with sustainability (Duivesteijn, 2003).

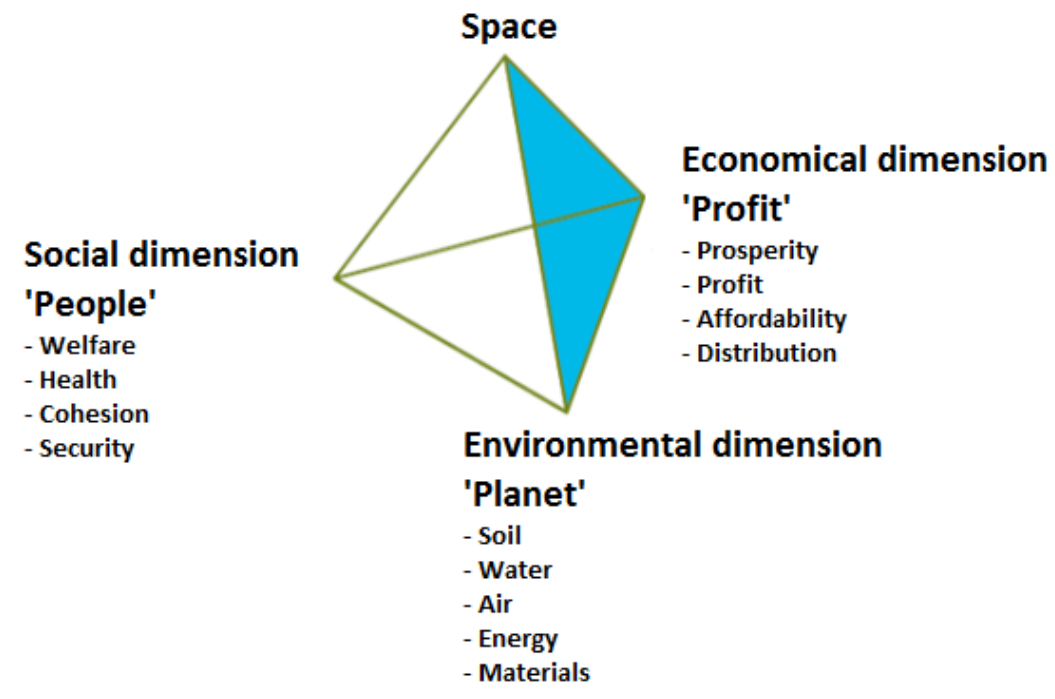

Figure 4. Duivesteijns Tetraëder. (Duijvestein, 2003)

Another manner in which Dutch literature reflects international literature is the complementation of different definitions of sustainability. One attempt was made by Rotmans (2001) who formulated the following definition: 'Sustainable development is a development that focuses at a dynamic balance between man, environment and economy. Not just in the present but also for future generations. The choices that have to be made are constantly focused on that balance. Such an integrated consideration requires insight in the long term societal influences of short term human activity" (Bos, 2010,. p. 16). Both influences of Brundtland (future generations) and Campbell and Elkington (balance between man, environment and economy) can be found in this definition. Although several attempts were made to contribute to the theoretical debate surrounding the concept of sustainable (spatial) development via Dutch literature the impact of those contributions on the international planning level are 
minimal.

As can be seen, influences from international literature are clearly found in Dutch literature where it continues along the same path, but at a more practical level. Dutch scientists and practitioners use, almost without exception, international literature as a starting point for their own research and literature. Contributions to the sustainability debate in Dutch literature often attempt to complement or fine-tune existing concepts or definitions of sustainable (spatial) development, such as the Triple $\mathrm{P}$ approach or the definition as formulated by the Brundtland report. These attempts are meant to increase their suitability for application by, in specific, Dutch governmental institutions such as municipalities.

\section{Results Part 3: Practical Application of Sustainable Development in the Netherlands}

Our third step in the research consisted of interviewing 10 municipalities to test the implementation of sustainability in Dutch planning practice. Municipalities are the lowest tier of government in the Netherlands and in that respect responsible for the implementation of sustainable objectives in planning processes. The data deriving from the interviews was analysed according to the eight themes mentioned before (see table 2): description and interpretation, definition, choice foundation, use of scientific sources, keeping up with developments, policy actualization, ambitions, and willingness to invest.

When municipalities where asked about their view on the concept of sustainable spatial development the interviewees considered it a very broad concept. Sustainability was viewed as a 'container' for a whole series of concepts. For example in Den Haag, sustainability was structured around seven themes, whereas in Oss it was reduced to ten focus points. Although a structured view is offered in themes or points, in all of the interviewed municipalities a focus on social sustainability was partially or completely lacking. A focus on safety and comfort for cyclists does show the adaptation of the concept to the Dutch perspective on sustainability. Improving the safety and comfort of cyclists is meant to increase the use of bicycles for every day traffic and reduce car usage. When questioned further about what kind of sustainable projects and policies the different municipalities had, it became clear the focus is the reduction of $\mathrm{co} 2$ emissions. Which means the general and broad approach in themes or focus points is adapted very narrowly into projects and policies. This can be considered quite odd when one takes into account the (theoretical) basis that most municipalities refer to, such as the Triple $\mathrm{P}$ approach, as this approach entails not only the environmental side of sustainability, but also involves social and economic sustainability, two pillars barely mentioned by municipalities. As such the interpretation of the sustainability concept can be considered very narrow.

In a similar manner, the definition used for sustainability also varies between municipalities. While some municipalities - such as Den Haag - refer to the Brundtland definition, others have their own definitions. Súdwest-Fryslân, for example, uses the definition of the Natural Step that defines sustainability as 'the ability of mankind to infinitely exist within the natural cycles" (The Natural Step, 2015). Still others utilize a more pragmatic approach of the concept of sustainable spatial development. Oss is one of those more pragmatic municipalities clearly stating that they assess the meaning of sustainability for each different situation. As such a variety of definitions is used, some based on international literature, while others choose their own, more pragmatic, visions.

At first glance the most important guideline in founding choices concerning sustainability is the manner in which municipalities interpret and define sustainability. Municipalities with a clear view such as Den Haag, which focuses on the Triple P approach, base their decisions on their view while keeping national rules and norms in the back of their mind. Municipalities who are more pragmatic take national rules and norms as starting point, while awaiting opportunities to become more sustainable. Second, the role of being an example is also significant. This means that regardless of how municipalities interpret sustainability or how serious their involvement is, when there is an apparent opportunity to become more sustainable they will take it to show off their willingness to adapt. A third factor simply entails: what is possible? The economic crisis and cohesive consequences such as the depletion of financial resources are also playing a major role in which decisions municipalities make concerning sustainable spatial development.

As mentioned earlier, the use of scientific sources is no necessity for municipalities to derive at sustainable development. A pragmatic approach can just as well be firmly substantiated. Nevertheless, having a scientific base for municipal policy still is seen as an indicator on how well a municipality is doing in regard to sustainability. In the previous paragraphs the Brundtland report and the Triple P approach are already mentioned as most used scientific resources. The measure to which they use these sources differs greatly. Three groups can be distinguished. The first is Den Haag, not because they use alternative sources, but because they are the most clear in their use of the Brundtland report and the Triple $\mathrm{P}$ approach. Second, is the municipality of 
Súdwest-Fryslân which uses the approach of the Natural Step (2015). This approach is not used by any other interviewed municipality. The third and last group includes the municipality of Rotterdam who focuses more on the climatological aspect of sustainability although they do implement Brundtland and the Triple $\mathrm{P}$ approach in their policies. What becomes apparent when looking at the overview of used literature is the small range of literature used by municipalities. Most municipalities only use the most well-known sources. Additionally, the used sources have a practical nature, the theoretical international literature, for example the anthropocentric versus ecocentric debate, is neglected. This can be considered coherent, taking into account that these theoretical debates do not deliver a direct and concrete contribution to municipal policy. What is more surprising is the neglect of practice-oriented Dutch literature, such as Duivesteijns tetraëder, while it can contribute to municipal policy. As such, most municipalities do have a scientific base for their policy, but the degree to which they use these sources differs greatly and a large portion of available literature is neglected.

When taking a look at how municipalities do keep track of recent developments, roughly two manners can be recognized. First, the municipality itself is actively searching for new developments. These municipalities employ staff to look for new developments and remain up to date. This can be done by reading scientific papers, newsletters, or by being part of networks related to the concept of sustainable spatial development. Second, keeping track is done in a passive manner. When municipalities use this method they refrain from actively searching for new developments themselves. Instead, they only form guidelines or rules to which new spatial development have to comply. Developers are free to use whatever techniques or developments they want as long as they comply to the guidelines formed by the municipality. In this way, the municipalities hope to stimulate developers to implement new developments in their plans. The downside is that developers are often able to comply to those guidelines using more conservative methods thus annihilating the impulse to innovate. This leaves the municipality without any possibility to assert further influence.

When considering policy actualization, the most used way to implement new developments in plans seems to be the passive manner mentioned in the previous paragraph. Even though, this means a lack of control of the implementation of sustainable objectives. Den Haag tackles this problem by so called 'sustainability paragraphs'. In these paragraphs developers have to describe in detail how they are planning to exploit 'sustainability opportunities', thereby allowing some control to the municipality in considering these opportunities. In some cases, to set an sustainable example, the municipality takes on a more active role, taking charge of a project and determining what has to be done and how it has to be done. It seems however that municipalities simply do not have the (financial) means to take on this role for every project, after which they relapse into a more passive role. A difficult issue is the implementation of new developments in ongoing projects. There are multiple examples of municipalities who wish to implement new sustainable innovations into their plans, but who are bound to contracts signed ten years ago. In that case municipalities often do not have any other choice than to resign and agree with a more passive role.

The passive manner in which municipalities keep track of developments and actualize their policies seems reason to believe the ambitions of the concerning municipalities are low. Still, there is a division in two groups with very ambitious or less ambitious policies, based on their length of involvement with sustainable development . Municipalities with a long track record in sustainable development, such as Etten-Leur and Wageningen, have highly ambitious policies. Others who are new to sustainable development, such as Sliedrecht and Harderwijk, stick to national guidelines in their sustainable policies. Nevertheless, in every municipality there are projects with higher and lower sustainable ambitions. This diversity makes a simple divide between 'sustainable' municipalities and 'unsustainable' municipalities not possible. In understanding the difference between more ambitious and less ambitious municipalities, two main reasons can be distinguished. The first is the background of the municipality. Towns or cities that traditionally have a more progressive and left-political background are often more ambitious concerning sustainability than municipalities with a more conservative background. Wageningen is a fine example hereof; being a very liberal and progressive town it is more involved in sustainability than municipalities as Harderwijk and Sliedrecht, with a more religious and conservative population. The second reason is the size of the municipality. In smaller towns the influence of a single person who holds the right (political) position is relatively large. A small municipality with a driven person on the right spot can therefore make giant leaps on a certain policy area. In larger municipalities such as Rotterdam and Den Haag the influence of a single person is smaller. Though, as there is more (public) focus on these larger municipalities because of their sheer size, they cannot fall behind too much as this will attract attention and criticism much faster than a small municipality which is unsustainable. In short, large municipalities seem to assume a more moderate approach to sustainability in general while smaller municipalities are often more extremely positioned, being either very sustainable or not sustainable at all, as a single person plays a relatively 
larger role.

Finally the willingness to invest was analyzed. The current economic situation is an important influence on the willingness to invest towards sustainable development. Multiple municipalities suggest that indeed there are ambitions concerning sustainable spatial development, but that they simply are not able to carry the financial burden that accompanies these ambitions. For example, in Harderwijk there simply is not enough budget to hire extra personnel to increase the effort on sustainability. An exception is Etten-Leur which was the only municipally that recently hired extra staff solely for sustainability. It should be noted that for the municipalities of Rotterdam and Den Haag it was very difficult to establish whether or not extra investments in sustainability have been made recently because of the sheer size of their organization. Nevertheless, many municipalities do state that when extra resources become available, sustainability is one of the topics most likely to invest in. Of course, that is easy to say and a hard to verify. Still our interviews verified that only a small number of municipalities give sustainability such a high priority, that they continue investing in sustainable development during times of economic adversity.

\section{Discussion and Conclusion}

In this article we set forth to discuss the trichotomy 'international scientific literature - national professional literature - planning practice' in relation to Dutch municipal sustainable (spatial) development, as contribution to the international academic debate. We questioned which literature municipalities use to interpret and define sustainability and sustainable spatial development, how they cope with the fast development of these concepts and how knowingly municipalities made choices in regard to these concepts. To answer this research question we discussed the most important discourses in international and Dutch literature adjoining the concept of sustainable spatial development. As such, we defined the gap between international literature and national literature in the field of sustainable (spatial) development. Afterwards we presented the results of the interviews that were held with the different Dutch municipal officers in eight themes, to investigate the gap between scientific research towards sustainable development (both internationally and nationally) and practices of sustainable development.

The research showed that the scientific literature used by municipalities to interpret and define sustainability and sustainable spatial development is rather limited. Most municipalities use the Brundtland report (1987), Campbells model (1996) and the Triple P approach by Elkington (1997). Newer and more extensive or application-oriented sources are used less often. As such Dutch municipalities do not redefine their practices based on new scientific insights, especially more fundamental insights in sustainable sciences. Nevertheless, how municipalities differ in their use of scientific literature as was demonstrated by the use of a more climate-based approach by the municipality of Rotterdam as a waterfront city. Furthermore, the operationalisation of sustainability in planning practices is more diverse than the use of literature. Although some municipalities clearly follow the doctrine of the Brundtland report and the Triple P approach, the majority of the municipalities use a more practical (pragmatic) approach, whereby literature is mentioned but hardly used in planning practices itself. As such, this research concludes that the gap between (inter)national sustainability science and national application of sustainability via planning practices still exists. To summarize (Dutch) municipalities do use scientific literature to a satisfactory level to interpret and define sustainable development, the implementation and use of the scientific literature in the actual planning practice leaves a lot to be desired.

Even though this research did not opt to understand what causes this discordance between sustainability science and sustainable planning practice - and appoint this matter for further research - the study did reveal two insights for further analysis. First, the manner in which municipalities include innovative (inter)national literature into their practices. Second, the financial resources at the level of implementation of sustainable policies. The first manner in which municipalities deal with new trends and insights in sustainability science can be typified as an active approach. When using this approach municipalities actively search for new developments to implement in new spatial planning practices. This requires a certain amount of effort, such as hiring employees to take up this task. The second way can be typified as a passive approach, in which municipalities simply leave space to private stakeholders to implement scientific insights in their plans. This approach has both positive and negative implications for sustainable development. On the one hand municipalities lose control of the implementation of sustainable objectives, on the other hand municipalities do not have to invest their (scarce) resources towards these objectives. Often municipalities mix these passive and active strategies towards sustainable objectives depending at the goal of a project and the culture of the municipality, but how this mix of passive and active strategy influences the application of innovation in sustainability science is still unclear. Furthermore, the choice for a strategy is dependent on the financial resources for implementation of (ambitious) sustainable policies. Even though municipalities claim to be very ambitious and use an active approach in their 
application of innovation in science - as showed by their policies - their resources might prevent implementation of these ambitious policy objectives. Subsequently, the choice is made to simply follow (less ambitious) national laws and regulations and wait for private stakeholders to implement more profound and ambitious sustainable development. As such, further research towards the financial incentives to implement innovative sustainable scientific insights is necessary.

\section{References}

Arts, B., \& Buizer, M. (2009). Forests, discourses, institutions A discursive-institutional analysis of global forest governance. Forest Policy and Economics, 11, 340-347. http://dx.doi.org/10.1016/j.forpol.2008.10.004

Barkemeyer, R., Holt, D., Preuss, L., \& Tsang S. (2014). What Happened to the 'Development' inSustainable Development? Business Guidelines Two Decades After Brundtland. Sustainable Development, 22, 15-22.

Blewitt, J. (2008). Understanding Sustainable Development. New York: Routledge.

Bond, A. J., \& Saunders, A. M. (2009). Sustainability appraisal: jack of all trades, master of none? Impact Assessment and Project Appraisal, 27(4), 321-329.

Bos, D. (2010). Duurzame gebiedsontwikkeling: van theorie tot praktijk. (Unpublished master's thesis). Universiteit Rotterdam, Technische Universiteit Delft, the Netherlands.

Campbell, S. (1996). Green Cities, Growing Cities, Just Cities? Urban Planning and the Contradictions of Sustainable Development. Journal of the American Planning Association, 62(3), 296-312. http://dx.doi.org/10.1080/01944369608975696

CBS. (2015). Kernindicatoren Nederland. Retrieved from http://www.cbs.nl/nl-NL/menu/cijfers/default.htm

Christen, M., \& Schmidt, S. (2012). A Formal Framework for Conceptions of Sustainability - A Theoretical Contribution to the Discourse in Sustainable Development. Sustainable Development, 20, 400-410.

Daly, H., \& Cobb, J. (1989). For the Common Good: Redirecting the Economy Towards Community, the Environment and a Sustainable Future. Ecological economics, 5(1), 267-273.

De Jong, M., Joss, S., Schraven, D., Zhan, C., \& Weijnen, M. (2015). Sustainable-smart-resilient-low carbon-eco-knowledge cities; making sense of a multitude of concepts promoting sustainable urbanization. Journal of Cleaner production. http://dx.doi.org/10.1016/j.jclepro.2015.02.004

De Zeeuw, F. (2011). Duurzame gebiedsontwikkeling: doe de tienkamp! Delft: TU Delft.

Duijvestein, C. A. J. (2003). De duurzaam bouwen reader: een nieuw beleidsinstrument. In Nationaal Dubo Centrum (Ed.), Dubo jaarboek 2004 (5) (pp. 17-24). Boxtel: Aeneas.

Elkington, J. (1997). Cannibals with Forks: The Triple Bottomline of the 21st Century business. Oxford: Capstone Publishing Ltd.

Feberwee, M., Mohammadi, S., Husslage, W., \& van Timmeren, A. (2010). DGO Duurzame gebiedsontwikkeling: 12 inspirerende projecten, 21e eeuw. Delft/Den Haag: Global Archs.

Felix, A. (2015). Duurzame bedrijventerreinen: een verschil tussen droom en daad? Een studie naar gezamenlijke duurzaamheidsmaatregelen op bestaande bedrijventerreinen in de provincie Utrecht. (Master's thesis, University of Utrecht, the Netherlands). Retrieved from http://dspace.library.uu.nl/handle/1874/311074

Gough, S., Scott, W., \& Stables, A. (2010). Beyond O’Riordan: Balancing Anthropocentrism and Ecocentrism. Research in Geographical and Environmental Education, 9(1), 36-47.

Graafland, J. J. (2002). Profits and Principles: Four Perspectives. Journal of Business Ethics, 35, 293-305.

Habermas, J. J. (1996). Three normative models of democracy. Constellations, 1(1), 1-10.

Hajer, M. A. (1995). The politics of environmental discourse. Ecological Modernization and the Policy Process. Oxford: Oxford University Press.

Haughton, G., \& Hunter, C. (1994). Sustainable Cities. Londen: Kingsley.

Hawken, P., Lovins, A., \& Lovins, L. (1999). Natural Capitalism: the Next Industrial Revolution. London: Earthscan.

Holzscheiter, A. (2014). Between Communicative Interaction and Structures of Signification: Discourse Theory and Analysis in International Relations. International Studies Perspectives, 15, 142-162. 
Hopwood, B., Mellor, M., \& O’Brien, G. (2005). Sustainable Development: Mapping Different Approaches. Sustainable Development ,13, 38-52.

Imran, S., Alam, K., \& Beaumont, N. (2011). Reinterpreting the Definition of Sustainable Development for a More Ecocentric Reorientation. Sustainable Development, 22, 134- 144.

Kambites, C. J. (2012). 'Sustainable Development': the 'Unsustainable' Development of a Concept in Political Discourse. Sustainable Development, 22, 336-348.

Kistenkas, F. (2014). Habitattoets heroverwogen: Belemmeringen van de habitattoets voor duurzame groei en evenwichtige gebiedsontwikkeling. Wageningen. Retrieved from http://library.wur.nl.proxy.library.uu.nl/WebQuery/wurpubs/482840

Kleindorfer, P. R., Singhal, K., \& Van Wassenhove, L. N. (2005). Sustainable Operations Management. Production and Operations Management, 14(4), 482-492.

Koops, J. (2012). Zelforganisatie in binnenstedelijke gebiedsontwikkeling een hype en/of de oplossing? (Master thesis, Erasmus University Rotterdam, the Netherlands). Retreived from http://thesis.eur.nl/pub/12280/

Lister, M., Dovey, J., Giddings, S., Grant, I., \& Kelly, K. (2003). New Media: A Critical Introduction. Londen: Routledge.

Luke, T. W. (2005). Neither sustainable nor development: reconsidering sustainability in development. Sustainable Development, 13, 228-238.

Opdam, P. (2009). Groen-blauwe netwerken in duurzame gebiedsontwikkeling. Wageningen: Habiforum / Wageningen UR.

Pearce, D., Markandya, A., \& Barbier, E. (1989). Blueprint for a Green Economy. London: Earthscan.

Raco, M. (2007). Building sustainable communities: spatial policy and labour mobility in post-war Britain. Bristol: Policy Press.

Rees, N. E., \& Roseland, M. (1988). Planning for Sustainable Development. Discussion paper no. 15, University of British Columbia, School of Community and Regional Planning: Vancouver.

Schmidt, V. A. (2008). Discursive Institutionalism: The Explanatory Power of Ideas and Discourse. Annual Review of Political Science. http://dx.doi.org/10.1146/annurev.polisci.11.060606.135342

Sharachchandra, M. (1991). Sustainable Development: A Critical Review. World Development, 19(6), 607-621.

Tanguay, G. A., Rajaonson, J., Lefebvre, J. F., \& Lanoie, P. (2010). Measuring the sustainability of cities: An analysis of the use of local indicators. Ecological Indicators, 10(2), 407-418. http://dx.doi.org/10.1016/j.ecolind.2009.07.013

The Natural Step. (2015). The Natural Step. Retreived from http://thenaturalstep.nl/

Van de Griendt, B. (2011). Omgaan met milieu en duurzaamheid bij vastgoed-en gebiedsontwikkeling: Wat ontwikkelaars moeten weten! Bouwfonds Ontwikkeling. Retreived from https://www.bpd.nl/media/83740/bpd_omgaan-met-milieu-en.pdf

Van den Brink, M., \& Metze, T. (2006). Words matter in policy and planning : discourse theory and method in the social sciences. Utrecht: Koninklijk Nederlands Aardrijkskundig Genootschap. Retreived from http://library.wur.nl.proxy.library.uu.nl/WebQuery/clc/1872312

World Commission on Environment and Development. (1987). Our Common Future. Oxford: Oxford University Press.

\section{Copyrights}

Copyright for this article is retained by the author(s), with first publication rights granted to the journal.

This is an open-access article distributed under the terms and conditions of the Creative Commons Attribution license (http://creativecommons.org/licenses/by/3.0/). 